\title{
Progeria : Pathogenesis and Oral Manifestation- A Review
}

\author{
Saigal S, Bhargava A
}

Department of Oral Pathology,

Government Dental College, Raipur (Chhattisgarh), India.

\author{
Corresponding Author \\ Sonal Saigal \\ Department of Oral Pathology, \\ Government Dental College, Raipur (Chhattisgarh), \\ Indial \\ Email: sonal_saigal@sify.com
}

Citation

Saigal S, Bhargava A. Progeria:Pathogenesis and Oral Manifestation- A Reviewl. Kathmandu Univ Med J 2012;37(1):72-6.

\begin{abstract}
Our life span is genetically programmed and it is possible that a defect in produced proteins encoded by the 'longevity' gene is a cause of aging. Progeria which is a rare, fatal genetic condition which affects between one in four million and one in eight million children of both sexes equally and characterized by premature and accelerated aging. The appearance and physiology of these children resembles to elderly people but they typically have life span to their mid teens. It is also known as the Hutchinson-Gilford syndrome, which was initially reported by Johnathan Hutchinson in 1886 and further described by Hastings Gilford in 1904. It is an autosomal recessive disorder, which means an individual has inherited a mutated gene from both parents. It is added to the expanding catalogue of 'laminopathies', diseases caused by mutations affecting nuclear lamina proteins known as lamin A (LMNA). In oral manifestation primary finding is micrognathia with delayed tooth eruption and incomplete formation of root of permanent tooth. Presently there are no known cures for this abnormality.
\end{abstract}

\section{KEY WORDS}

Hutchinson-Gilford Progeria Syndrome (HGPS), Premature aging, Progeria.

\section{INTRODUCTION}

The word "Ageing" does not give a good feeling to most of us because of problems and diseases associated with ageing. Many individuals take megadoses of vitamin E; drink Kombucha tea etc., all in the hope of finding the "fountain of youth". According to social, behavioural, physiological, morphological, cellular and molecular changes, ageing can be considered in many different ways. In recent years ageing has become the social and political agenda. Ageing stories, particularly anti-ageing therapies, are a big attraction in newspapers and magazines. Although etiology of aging is important to understand, but it is equally important to differentiate the normal physiological changes from those associated with diseases. ${ }^{1}$ Aging can be characterized, according to Helfand and Rogina, as an inevitable consequence of being a multicellular organism; associated with a random, passive decline in function; leading to a global loss of homeostasis over time; and mortality increasing with age. ${ }^{2}$ Progeria is a rare, multisystem but devastating disorder affecting various tissues and organs like bone, muscle, skin, subcutaneous tissue, vessels and heart that mimic premature aging. ${ }^{3}$ There are two types of progeria namely:

\section{1)Hutchinson-Gilford Progeria Syndrome}

It occurs in about one in eight million children. Signs of progeria begin to show around six to twelve months when the baby fails to gain weight and skin changes occur. The characteristic features of this syndrome includes: baldness, prominent scalp, veins and eyes, small jaw, delayed tooth formation, thin limbs with prominent joints, short stature, joint stiffness, hip dislocations, thickened, tight and shiny skin over joints. Average life expectancy is 13 years, with approximately $75 \%$ dying from heart disease. ${ }^{4}$

\section{2)Werner Syndrome (adult progeria)}

It occurs in about one in one million individuals. First sign of syndrome is around puberty when the child fails to have a normal growth spurt, or may be delayed until an individual is as old as 30 years. The characteristic features of this syndrome includes: striking difference between person's appearance and his/her real age, greying hair and/or balding, wrinkling and aging of the face, sunken cheeks, small jaw, small stature (usually less than $1.6 \mathrm{~m}$ tall), muscle weakness, thickened, tight and shiny skin over joints, leading to ulcers, high-pitched voice is noted. Death usually occurs in patients between $30-50$ years, with most dying from heart disease or cancer. ${ }^{4}$ 


\section{HISTORY}

In 1886, the general practitioner Jonathan Hutchinson described a three and half year-old boy with congenital absence of hair and mammary glands with atrophic condition of the skin and its appendages. He thought it was a form of ectodermal dysplasia. A second patient was mentioned briefly by Hutchinson in 1895 but described in much more detail by Hastings Gilford (1897) who had followed the patient for several years until his death at 17 years. Hastings Gilford in 1887 suggested naming the entity 'progeria,' 'pro' meaning early and 'geras' meaning old age in ancient Greek. ${ }^{5}$

\section{EPIDEMIOLOGY}

It is a rare condition with a reported incidence of one in eight million births. ${ }^{6}$ The mean age of death is at age 13 years, most commonly due to atherosclerosis. It is mainly sporadic in occurrence, but a genetic cause has now been implicated following the identification of de novo heterozygous mutations in the LMNA gene in the majority of progeria patients. A single family showing autosomal recessive inheritance of homozygous LMNA mutations has also been reported. ${ }^{7}$

\section{PATHOGENESIS}

The nucleus is the defining feature of eukaryotic cells and is separated from the cytoplasm by the nuclear envelope (NE). The NE is composed of three distinct elements, i.e., the nuclear membrane, nuclear pore complexes, and the nuclear lamina, in which the nuclear membrane is a doubleunit membrane whose outer nuclear membrane (ONM) is continuous with and shares biochemical and functional properties with the endoplasmic reticulum (ER). The inner nuclear membrane (INM) is distinct from ONM and ER which is defined by a subset of integral membrane proteins, termed nuclear envelope transmembrane proteins (NETs) that are anchored to the INM during interphase. ${ }^{8}$

Recently, interest in the NE has intensified after the discovery of mutations in either protein of the nuclear membrane or lamins or nuclear pore complexes (NPC) proteins which give rise to a wide range of inherited diseases, collectively termed either nuclear envelopathies if mutations arise in inner nuclear membrane INM or NPC proteins, or laminopathies if mutations arise in lamins. The association of NE proteins with such a wide range of diseases implies important functions for these proteins in the normal development and/or maintenance of many different tissue types. Indeed, many NE proteins have differential expression profiles during development and have been implicated in a range of cellular functions including the maintenance of cellular architecture, apoptosis, DNA replication, and transcription. ${ }^{8}$

Mammals possess three lamin genes, namely lamin B1 (LMNB1), lamin B2 (LMNB2) genes and the developmentally regulated lamin $A / C$ gene (LMNA). B-type lamins form the fundamental constituents of the nuclear envelope which are essential for cell viability and normal embryonic development whereas A-type lamins have more specialized functions in terminally differentiated cells, fulfilling essential functions in organ and tissue homeostasis. They include two major products lamin A and C which are expressed in virtually all differentiated somatic cells. ${ }^{9}$ Although the A-type lamins are widely expressed, LMNA mutations are responsible for different clinically defined disorders with tissue-selective abnormalities. ${ }^{10}$ Genetic studies since the late 1990s have shown that mutations in LMNA cause about a dozen clinical disorders with different names (Table 1). These can more broadly be classified into diseases affecting predominantly in adipose tissue, striated muscle, peripheral nerve, or multiple tissues resulting in progeroid phenotypes. ${ }^{11}$

Table 1. Mutations in LMNA cause several distinct clinical diseases predominantly affecting adipose tissue, striated muscle and giving a progeria phenotype.

\begin{tabular}{|c|c|c|}
\hline Adipose Tissue & Striated Muscle & Progeria Phenotype \\
\hline $\begin{array}{l}\text { 1.Dunnigan-type } \\
\text { familial partial lipo- } \\
\text { dystrophy }\end{array}$ & $\begin{array}{l}\text { 1.Autosomal } \\
\text { dominant (and rarely } \\
\text { recessive) }\end{array}$ & $\begin{array}{l}\text { 1. Hutchinson-Gilford } \\
\text { progeria syndrome }\end{array}$ \\
\hline $\begin{array}{l}\text { 2.Lipoatrophy with } \\
\text { diabetes and other } \\
\text { features of insulin } \\
\text { resistance }\end{array}$ & $\begin{array}{l}\text { 2.Emery-Dreifuss } \\
\text { muscular dystrophy }\end{array}$ & $\begin{array}{l}\text { 2.Atypical Werner } \\
\text { Syndrome }\end{array}$ \\
\hline $\begin{array}{l}\text { 3.Atypical lipodystro- } \\
\text { phy syndromes }\end{array}$ & $\begin{array}{l}\text { 3.Cardiomyopathy } \\
\text { dilated } 1 \mathrm{~A}\end{array}$ & $\begin{array}{l}\text { 3.Variant progeroid } \\
\text { disorders }\end{array}$ \\
\hline $\begin{array}{l}\text { 4.Mandibulo-acral } \\
\text { dysplasia }\end{array}$ & $\begin{array}{l}\text { 4.Limb-girdle muscu- } \\
\text { lar dystrophy type } 1 B\end{array}$ & \multirow{3}{*}{$\begin{array}{l}\text { 4.Mandibulo- } \\
\text { acral Dysplasia } \\
\text { which is a features } \\
\text { of lipodystrophy and } \\
\text { progeria.11 }\end{array}$} \\
\hline 5.Peripheral Nerve & $\begin{array}{l}\text { 5.Congenital muscu- } \\
\text { lar dystrophy }\end{array}$ & \\
\hline $\begin{array}{l}\text { 6.Charcot-Marie- } \\
\text { Tooth disease type } \\
\text { 2B1 }\end{array}$ & $\begin{array}{l}\text { 6."Heart-hand" } \\
\text { syndrome }\end{array}$ & \\
\hline
\end{tabular}

Other researchers showed that progeria may arise randomly due to a single letter change in one gene of the child's DNA. 12-14 The mutation believed to occur in the father's sperm before conception that results in the production of a toxic protein that attaches to and distorts the nucleus (the cell's command center containing its genetic material). Although cells normally multiply during growth and development, the misshapen nucleus cannot divide properly, ultimately damaging cells and accelerating the aging process. ${ }^{12}$ It also has been demonstrated that patients with progeria have pronounced shortening of telomeres thus; telomere length may serve as a biologic clock regulating the life span of normal cells. It is thought that telomeres become shorter with time because of a decrease in activity of the enzyme telomerase, which is responsible for the maintenance of the normal telomeres length. ${ }^{13}$ Few other researches has focused on a link between progeria and aging, among other topics, has evaluated the role of fibroblast life span, immune function, endocrine function, lipofuscin accumulation, thermolabile enzymes, atherosclerosis, and hyaluronic acid excretion (Table 2 ).$^{14}$ 
Table 2. Studies and researches focusing link between progeria. and aging.

\begin{tabular}{|c|c|}
\hline $\begin{array}{l}\text { Fibrobl } \\
\text { span }\end{array}$ & $\begin{array}{l}\text { udies have shown that cultured fibroblasts from patients with progeria have demonstrated a significant (nine-tenths) reduction in } \\
\text { ellular life span, when compared with age-matched control subjects. }\end{array}$ \\
\hline $\begin{array}{l}\text { Immune func- } \\
\text { tion }\end{array}$ & $\begin{array}{l}\text { An abnormal immune function resulted due to decreased numbers of HLA cell-surface markers. However no abnormality was dem- } \\
\text { onstrated in the number/function of HLA antigens. }\end{array}$ \\
\hline Endocrine & $\begin{array}{l}\text { Studies revealed that insulin binding to nonspecific receptors was reduced in progeria cells, while specific receptor binding ap- } \\
\text { peared to be normal. However the finding is not clear at present. }\end{array}$ \\
\hline $\begin{array}{l}\text { Lipofuscin ac- } \\
\text { cumulation }\end{array}$ & $\begin{array}{l}\text {-matched control subjects. Studies supported this showing normal qualitati } \\
\text { th progeria when compared with age matched control subjects. }\end{array}$ \\
\hline & $\begin{array}{l}\text { Increased thermolability of certain enzymes may parallel the age-associated accumulation of lipofuscin and compromise cell func- } \\
\text { tion. Accordingly, the abnormal thermolability of glucose-6-phosphate dehydrogenase, hypoxanthine phosphoribosyltransferase, } \\
\text { and } 6 \text {-phosphogluconate dehydrogenase has been demonstrated in progeria fibroblasts, but again, further studies have challenged } \\
\text { this by showing no consistent derangement. }\end{array}$ \\
\hline Atherosclerosis & $\begin{array}{l}\text { Is an invariable finding in every autopsy case of progeria. Also, hyperlipidemia in the form of increased low-density lipoprotein levels } \\
\text { and increased /3-lipoprotein and pre-/3-lipoprotein levels has been documented, as well as low levels of high-density lipoprotein } \\
\text { and increased serum cholesterol levels. However, as hyperlipidemia is not a uniform and is not uncommon for normal young adults } \\
\text { to exhibit signs of atherosclerosis, these findings are of questionable significance. }\end{array}$ \\
\hline $\begin{array}{l}\text { Hyaluronic acid } \\
\text { (HA) excretion }\end{array}$ & $\begin{array}{l}n \text { the second decade of life, HA constitute approximately } 1 \% \text { of glycosaminoglycans, whereas in fifth to seventh decades of life, it } \\
\text { onstitutes circa } 6 \% \text { of glycosaminoglycans. This suggests that HA may be a normal feature of advancing age. Progeria may be an } \\
\text { xample of the effect of increased HA and concomitant reduced vascularity. }\end{array}$ \\
\hline
\end{tabular}

Table 3. Common clinical features in Werner's syndrome, HGAS and aging are given in Table 3., ${ }^{1,5,15}$.

\begin{tabular}{|c|c|c|c|}
\hline Features & $\begin{array}{l}\text { Werner's } \\
\text { syndrome }\end{array}$ & HGAS & $\begin{array}{l}\text { Common } \\
\text { aging }\end{array}$ \\
\hline MIM number & 277700 & 176670 & .. \\
\hline Causative gene(s) & WRN, LMNA & LMNA & $\begin{array}{l}\text { Unknown } \\
\text { or } \\
\text { Inaplcable }\end{array}$ \\
\hline Genetics & $\begin{array}{l}\text { Autosomal } \\
\text { recessive }\end{array}$ & $\begin{array}{l}\text { Sporadic, } \\
\text { autosomal } \\
\text { dominant }\end{array}$ & $\begin{array}{l}\text { Inappli- } \\
\text { cable }\end{array}$ \\
\hline Onset & $\begin{array}{l}\text { Young } \\
\text { Adulthood }\end{array}$ & Childhood & $\begin{array}{l}\text { Late } \\
\text { Adulthood }\end{array}$ \\
\hline Weight range (kg) & $30-45$ & $0-15$ & Variable \\
\hline Hair graying & + & + & + \\
\hline Hair loss & Male pattern & Total & + \\
\hline Skin thinning & + & + & + \\
\hline Subcutaneous tissue loss & + & + & _- \\
\hline Skin calcification & + & - & - \\
\hline Ankle ulceration & + & _ & _ \\
\hline Hyperkeratosis & + & - & _- \\
\hline Cataracts & + & _ & + \\
\hline Short stature & + & + & Variable \\
\hline Coxavalga & - & + & _ \\
\hline Atherosclerosis & + & + & + \\
\hline Osteopenia/osteoporosis & + & + & + \\
\hline Cancer susceptibility & + & _ & Variable \\
\hline $\begin{array}{l}\text { Laryngeal atrophy (high } \\
\text { voice) }\end{array}$ & + & + & - \\
\hline Diabetes & Variable & - & Variable \\
\hline Hypogonadism & + & + & Variable \\
\hline Thymic atrophy & + & _ & + \\
\hline
\end{tabular}

Note: $\mathrm{MIM}=$ Mendelian inheritance in man, +=present, -=absent.

\section{ORAL MANIFESTATIONS}

\section{A) Jaws:}

In progeria micrognathia is the primary manifestation with comparative paucity of vertical growth. Mandible is hypoplastic with short ramus and obtuse mandibular angle. The palatal vaults are narrow and high whereas the alveolar process is atrophic. The maxillary arch is small therefore overall craniofacial disproportion is seen. ${ }^{16}$

\section{B) Teeth and its development:}

It is associated with delayed tooth eruption with delayed loss of deciduous teeth and overcrowding therefore extraction of over retained primary teeth is advised..$^{17,18}$ There is a high caries incidence. Incomplete and abnormal formation of roots of primary molars whereas in permanent teeth delay and irregular calcification of the crowns are seen. Anodontia, hypodontia and enamel hypoplasia is also seen in some cases. Lateral incisors located lingually and palatally. Discoloration of teeth are also noted in some cases. ${ }^{16,19}$

\section{C) Other features:}

There is a reticular atrophy of pulp with narrow pulp chambers, calcification along the nerve fibers and the vascular walls are found. ${ }^{16}$ Severe osteolysis with pathological fractures are also evident in some cases. ${ }^{19}$

\section{HISTOPATHOLOGICAL FEATURES}

Skin, bone, and cardiovascular tissue exhibit the most prominent histologic changes. In the skin, a normal to atrophic epidermis is observed with an increase in the basal layer of melanin. The dermis reveals thickened and disorganized collagen fiber bundles with areas of hyalinization, whereas elastic fibers appear to be 
unaffected. Blood vessel density is normal to decreased, and broadening of the vascular walls results in narrow channels. Sebaceous glands and hair follicles are decreased in number. Sweat glands are normal to only slightly decreased in amount. The subcutaneous layer is affected by a loss of adipose tissue..$^{1,5,14}$

Cardiovascular findings are especially important because of the associated high incidence of mortality. Atherosclerotic plaques, calcifications in the mitral and aortic valves, ventricular dilatation and hypertrophy are also seen. ${ }^{14}$

\section{DIAGNOSIS}

There is no biochemical test to diagnose progeria. These patients may excrete increased amounts of hyaluronic acid, but the underlying molecular defect is unknown. It is uncertain whether abnormal findings such as insulin resistance or an increased basal metabolic rate (BMR) occur in all individuals with progeria. ${ }^{19}$ Although the diagnosis of HGPS is usually straightforward, and the classically affected patients strongly resemble one another. However, there is a group of patients with progeria that show a definite overlap with patients with mandibulo-acraldysostosis (MAD). Their clinical findings differ from classical HGPS in several respects:

a) Growth is less retarded, adult heights varying from 130 to $145 \mathrm{~cm}$, while in classical HGPS height rarely exceeds $115 \mathrm{~cm}$;

b) In many, scalp hair persists much longer, and may not disappear completely even in old age;

c) The lipodystrophy progresses more slowly with fat pads remaining in the cheeks, submandibular region, and pubis into adulthood;

d) Osteolysis is more severe in all affected bones (vault, mandible, clavicles, ribs, distal phalanges) except for the viscerocranium where it is mild in childhood and only gradually progresses later on. The more severe osteolysis increases the risk of fractures, especially of the humerus, often at a young age (in 10 of the families, affected children had fractures, usually from the age of two to three years);

e) The incidence of consanguinity is increased (four in fourteen families);

f) The chance of survival into adulthood is somewhat increased (four cases having reached an age of 20 years or above). ${ }^{5}$

\section{FUTURE ASPECT}

The children with progeria undergo coronary artery bypass surgery and/or angioplasty in attempts to ease the life-threatening cardiovascular complications caused by progressive atherosclerosis. ${ }^{3}$ However, there currently is no treatment or cure for the underlying condition. Death occurs on average at age 13; usually from heart attack or stroke. ${ }^{20}$ Researchers published cell culture and mouse model studies that support a potential drug treatment for children with Progeria. Farnesyltransferase inhibitors (FTIs), originally developed for cancer, are capable of reversing the dramatic cell structure abnormalities that are the hallmark of cells from children with Progeria. Studies on progeria also examined the damage the mutant protein does to blood vessel cells of humans and mice. ${ }^{21}$ The discoveries offer increased hope for a cure for progeria and may also provide key insight into the cause of adult heart disease.

\section{REFERENCES}

1. Lata H, Walia L. Ageing: physiological aspects. JK Scie 2007;9:111-5.

2. Hamet P,Tremblay J. Genes of aging. Metabolism 2003;52:5-9.

3. Pilarczyk MA, Kmieć T, Fidziańska A, Rekawek J, Niebrój DI, Turska KA et. al. Progeria caused by a rare LMNA mutation p.S143F associated with mild myopathy and atrial fibrillation. Euro I paedneurol 2008;12:427-30.

4. Dermnet NZ.Premature aging syndromes (progeria) [Internet]. 2008 [updated 2008 March 10; cited 2008 Jul 1]. Available from: http:// www.dermnetnz.org/systemic/progeria.html.

5. Hennekam R.C.M. Hutchinson-Gilford Progeria Syndrome: Review of the Phenotype. American J Med Gene 2006;140:2603-24.

6. Abdenur J.E, Brown W.T, Friedman S, Smith M, Lifshitz F. Response to nutritional and growth hormone treatment in progeria. Metabolism 1997;46:851-6.

7. Shackleton S, Smallwood D.T, Clayton P, Wilson L.C, Agarwal A.K, Garg A. Compound heterozygous ZMPSTE24 mutations reduce prelamin: A processing and result in a severe progeroid phenotype. J Med Genet 2005;42:36-9.

8. Broers J.L.V, Ramaekers F.C.S, Bonne G, Ben R, Hutchison C.J. Nuclear Lamins: Laminopathies and their role in premature ageing. Physiol Rev 2006;86:967-1008.

9. Lourdes D, David A. Prematurely aged children: Molecular alterations leading to Hutchinson-Gilford Progeria and Werner Syndromes. Curr Aging Sci 2008;1:202-12.

10. Brian B, Colin L.S. The Laminopathies: The functional architecture of the nucleus and its contribution to disease. Ann Rev Genomics Human Gen 2006;7:369-405.

11. Howard J, Ceciliao S, Yuexia W. Diseases of the Nuclear Envelope. Cold Spring Harb Perspect Biol 2010;2:1-17.

12. Barbara J. New hope for Progeria: Drug for rare aging disease. Sci Ameri 2008;8:2-7.

13. Secerbegovic $S$. A hypothesis that aging results genetically produced proteins from defects in genetically produced proteins. Med Hypo 1997; 48: 531-3.

14. Anthony J.B. Progeria. Arch Dermol 1989;125:21-9.

15. Robert $\mathrm{AH}$. Drawing the line in progeria syndromes. Lancet 2003;362:416-7.

16. Maloney $W$. The integral role of the dentist in treating individuals with Hutchinson-Gilford Progeria Syndrome. Webmedcentral 2010;1:1-3.

17. Suri L, Gagari E, Vastardis H. Delayed tooth eruption: Pathogenesis, diagnosis, and treatment. A literature review. Am J Orthod Dentofacial Orthop 2004;126:432-45. 
18. Linda $S$, James $P$, Kamat D. Common pediatric dental dilemmas. Clin Pediatr Phila 2008;47:99-101.

19. Russo-menna I, Arancibias C. The Hutchinson's Gilford progeria syndrome - A case report. Minerva Anestesiol 2010;76:151-4.
20. Abdenur J.E, Ted W, Friedman S, Smith M, Lifshitz F. Response to nutritional and growth hormone treatment in progeria. Metabolism 1997;46:851-6.

21. National Institutes of Health [homepage on the Internet]. U.S.A: The Society; 2010. Available from: www.nih.gov/about/ researchresultsforthepublic/Progeria.pd.f. 